\title{
The Geo-Politics for Preventing Human Trafficking in Indonesia: A Lesson Learn from Maritime State
}

Muhammad Pathan Ramadhan ${ }^{1}$, Jihan Syahida Sulistyanti ${ }^{2}$

${ }^{1}$ Faculty of Social and Political Sciences, Universitas Indonesia

${ }^{2}$ Human Advocacy and Justice Forum, Semarang Faculty of Law, Universitas Negeri Semarang, Indonesia Corresponding Author: J. S. Sulistyanti, email: jsyahida@gmail.com

\begin{abstract}
In this modern era, the borders between one country and another began to disappear. The existence of this condition full of freedom facilitates the occurrence of human trafficking. Human trafficking is a very complex problem. Like Indonesia, along with the development of the times, the threat of human trafficking has increased. This paper is intended to analyze how Indonesia deals with Human Trafficking Cases? The paper analyzes the effort of government on multi-sectoral and implementation of laws and regulation on handling the case. The research uses doctrinal legal research with normative legal approach. The research highlighted and illuminated that the swift flow of globalization and the very strategic geographical conditions and with the vast sea area allows Indonesia as an area traversed by international human trafficking routes. To address this problem, for the sake of the safety and comfort of Indonesian citizens, it is necessary to apply a total and integrated problem-solving model, especially in the maritime field.
\end{abstract}

Keywords: Human Trafficking; Maritime State; Maritime Security; Globalization Impact

\section{How to cite:}

Ramadhan, M. P., \& Sulistyanti, J. S. (2020). The Geo-Politics for Preventing Human Trafficking in Indonesia: A Lesson Learn from Maritime State. Indonesian Journal of Advocacy and Legal Services, 2(2), 277-290. https://doi.org/10.15294/ijals.v2i2.37925

\section{A. Introduction}

The Unitary State of the Republic of Indonesia (NKRI) is an archipelago state that stretches for five thousand kilometers along the equator. If viewed 
according to geostrategic, Indonesia lies in a cross position between two continents and two oceans. Being between two continents makes Indonesia surrounded by very different differences in civilization, namely western (Australian) civilization and eastern civilization (Asia). While the geostrategic location of Indonesia which is located between the Indian and Pacific oceans makes Indonesia a busy international shipping lane. ${ }^{1}$ This certainly influences civilization in Indonesia. Especially in today's era of globalization has a great influence on the civilization of a country. Globalization $^{2}$ brings the flow of human movement to be more free to move from one country to another. Globalization causes loss of boundaries between jurisdictions. ${ }^{3}$ As an archipelagic country, the sea has a very important function for NKRI (The Unitary State of the Republic of Indonesia) that is the sea as a unifying media, transportation media, resource media, defense and security media, and media diplomacy. Based on an understanding of the marine function of the importance of the Indonesian sea, there are many the sea which can cause problems in handling crime in the sea such as smuggling, transnational crime, and Human Trafficking. ${ }^{4}$ This raises state concerns, so that some countries carry out stronger maritime security cooperation to protect their economic activities and prevent illegal activities. Every effort through maritime policy does not have a significant impact on water stability and security. Success in identifying several sources of threats will definitely lead to understanding how to manage collaboration to overcome certain threats and challenges. ${ }^{5}$

The definition of trafficking in the Law on the Eradication of the Crime of Trafficking in Persons (Law No. 21 of 2007) is broader than that of the Criminal Code, by including the process and definition of victims and perpetrators. Article 1 number (1) Law No. 21 of 2007 defines trafficking as follows: "Trafficking is the act of recruiting, transporting, sheltering, sending, transferring or receiving someone with the threat of violence, use of violence, kidnapping, confinement, forgery, fraud, abuse of power or vulnerable

1 Eka Martiana Wulansari, "Penegakan Hukum Laut Dengan Sistem Single Agency Multy Tasks." Rechts Vinding. https://rechtsvinding.bphn.go.id/jurnal_online/PENEGAKAN\%20HUKUM\%20DI\%20LA UT\%20DENGAN\%20SISTEM\%20SINGLE\%20AGENCY\%20MULTY\%20TASKS.pdf (accessed Desember 1, 2018)

2 George Ritzer, The Globalization of Nothing (Yogyakarta: Atmajaya University,2010)

3 Annisa Jihan Andari. "Analisis Viktimasi Struktural Terhadap Tiga Korban Perdagangan Perempuan dan Anak Perempuan.” Jurnal Kriminologi Indonesia 7.3 (2011):307.

4 Ibid.

5 Anonim. "Isu Keamanan Maritim Regional". Tabloid Diplomasi, September 15, 2010. http://www.tabloiddiplomasi.org/isu-keamanan-maritim-regional/ (accesed September 2, 2018) 
positions, entrapment debt or giving payments or benefits, so that the consent of many people who take control of others is obtained, whether done within the State or between countries, for the purpose of exploitation or causing people to be exploited." From this definition, there are three main elements of trafficking, namely:

1) Move people, both inside and outside the national boundaries (including recruitment, transportation, shelter, shipping, transfer or reception).

2) Methods against the law (including threats, use of power, kidnapping, confinement, forgery, fraud, abuse of power or vulnerable positions, debt bondage or providing payments or benefits so as to obtain approval from the person in control of the other person).

\section{B. Method}

This paper used doctrinal legal research with normative legal research. The research only compares and analyzes the existings cases in Indonesia by assuming and analyzing with some legal and political theories. The research has intersection between law and political sciences.

\section{Result and Discussion}

\section{Human Trafficking in Indonesia: Between the Fact and Illusion}

Human trafficking is a form of transnational crime, ${ }^{6}$ because it is carried out by involving a network of transnational crime. In Indonesia, this crime of trafficking is a crime that must be dealt with thoroughly by Indonesian law enforcement officials, such as the National Police and several other security apparatuses. Security forces and law enforcement officials are required to uncover various trafficking practices. Given that the practice of human trafficking is a network that involves many actors, the handling process does not only involve one agency. The government must help collaborate with various related parties, such as immigration, the TNI, the community, the central government, local government, UNHCR, and other relevant parties. human trafficking between countries violates the provisions of the official provisions of both countries. ${ }^{7}$

6 Linda Jayanti,Steven Ray Sentinuwo, et.al. "Analisis Pola Penyalahgunaan Facebook Sebagai Alat Kejahatan Trafficking Menggunakan Data Mining." E-jpurnal Teknik Informatika 8.1 (2016):30.; Adiningrum Puspahapsari. "Implementasi CounterTrafficking International Organization for Migration (IOM) Dalam Menanggulangi Perdagangan Manusia Di Indonesia Tahun 2007-2013).” Journal of International Relations 1.3 (2015):2

7 Philip Martin,Mark Miller. "Smuggling and trafficking: A Conference Report" International Migration Review 34.3 (2000):969-975 
In Indonesia, human trafficking has increased after the tsunami that occurred at the tip of the island of Sumatra, compared to 2004, the human trafficking rate increased in 2005 and subsequently a rapid increase in $2006 .{ }^{8}$ The trafficking rate increased rapidly in 2006 , p. this is due to the occurrence of trafficking actions several weeks or months after the tsunami disaster occurred in Aceh. According to the Trafficking in Persons (TIP) report system, Indonesia is in a Tier 2 position. This position has the intention that countries whose governments have not met the minimum standards for the protection of Trafficking Victims Protection Act (TVPA) in 2000, Indonesia still shows effort and improvement to meet these standards. ${ }^{9}$

The problem of human trafficking is a crime that must get attention, not just the attention of the regional community, but the international community. Human trafficking cannot be resolved alone by a country, but must be resolved by involving many countries, through various coordination, communication, negotiations and joint regulations. The handling of human trafficking together is very appropriate considering the flow of human trafficking involves many countries that it passes. ${ }^{10}$

Crime of trafficking in persons always has very serious consequences for victims and their families, communities and countries. Various state conditions, namely countries that are the destination countries for trafficking in persons, transit countries or the source countries of trafficking in persons, such as those experienced by Indonesia. ${ }^{11}$ This human trafficking has been a problem for Indonesia for a long time. Indonesian waters is one that is often used as a pathway to their destination country, namely Australia. The perpetrators of this illegal trade apparently still have the impression of entering Indonesia easily.

This is one of the strong reasons for the perpetrators to use Indonesia as a jumping stone from their destination to Australia. The other main reason is Indonesia's strategic position as a country that borders directly with Australia. To be able to enter Australia, the most likely route (from many cases that occur) is by land and sea rather than by air. In addition, the shape of the Indonesian archipelago makes immigrants enter various doors in Indonesia. From the cases, the trafficked traffickers were more likely to enter Indonesia by land, namely from Malaysia, then enter the island of Sumatra, to Java with southern West Java (Serang) and southern East Java as the exit for to Christmas Island. The land and sea routes are often combined with

Ibid.

9 Angela Narwastu Andrasukma. "Kerjasama Pemerintah dan INGO terhadap Child Trafficking di Thailand tahun 2008-2013." Jurnal Analisis Hubungan Internasional 3.1 (2014):859.

10 Friebel, Guido \& Sergei Guriev. "Smuggling Human: A Theory of Debt-Financed Migration” Journal of The European Economic Associaton 4.6 (2006):1085-1111.

11 Noer Indriati. "Pengembangan Model Perlindungan Hukum Terhadap Anak Sebagai Korban Perdagangan di Indonesia.” Jurnal Dinamika Hukum 14.3 (2014):407. 
airways, considering that many are caught in Batam Island Airport, in Riau Province and in Surabaya. ${ }^{12}$

\section{Why Human Trafficking Happened in Indonesia? Some Trigger Factors}

\section{a. Indonesia's geographical location}

Indonesia is the largest archipelago in the world with an ocean area reaching 5.8 million $\mathrm{km} 2$, almost $2 / 3$ of its territory is the ocean. The position of Indonesia which is at the crossing point of the world makes Indonesia's sea area so strategic as a service route and trade by ships in the world. ${ }^{13}$ After 71 years of independence, Indonesia seemed to carry the sea it had. Many efforts have been made by the government to safeguard Indonesia's maritime security, but these efforts have not always gone smoothly. One obstacle is the threat of maritime crime. When viewed from Indonesia's strategic choke points that are often traversed by shipping vessels of various kinds of world trade commodities, such as the Strait of Malacca, the Strait of Lombok, and the Strait of Makassar. ${ }^{14}$ This is an attraction for maritime criminals to carry out their actions. These marine crime groups are divided into three, namely groups that use weapons in carrying out their operations, groups that do not use weapons, and maritime terrorism. ${ }^{15}$ Based on data reported by Bakamla from its official website, there were 169 cases of smuggling in the Indonesian sea from January to September 2015. The smuggling includes people, wood, fuel, drugs, alcohol, animals and goods. The threat of maritime crime in Indonesia is expected to continue to grow, along with the increasing economic activity in Indonesian waters. Moreover, in the future the world trade center will be more focused on the Asian region, given the increasing number of Asian population.

These threats not only have an impact on Indonesia's economic growth and security, but also have an impact on Indonesia's image in the international world. ${ }^{16}$ As the country with the second longest coastline in the world with a coastline of $81,900 \mathrm{~km}$, Indonesia is faced with a complex border problem. The situation of Indonesia as an archipelagic country separated by

12 Agus Subagyo. "Penyelundupan Manusia dan Ancaman Keamanan Maritim Indonesia." Jurnal Pertahanan 3.3 (2013):155-157.

13 Anta Maulana Nasution, Surya Wiranto, \& Adnan Madjid. "Sinergi Antara Kelompok Masyarakat Pengawas (POKMASWAS) dan pembinaan Desa Pesisir (BINDESIR) Untuk Membentuk Satuan Armada Nelayan (SATARMANEL) Dalam Rangka Mencegah Ancaman Keamanan Maritim” Jurnal Keamanan Maritim 4.1 (2018):26

14 Nainggolan, Agenda Poros Maritim Dunia dan Perubahan Lingkungan Strategis (Jakarta: P3DI,2015)

15 Paul Shemella, Introduction of Maritim Violence, Global Response to Maritime Violence (Palo Alto: Stanford University Press,2016)

16 Ibid. 
the sea which is traversed by the world trade route is very possible for illegal trade such as human trafficking by utilizing vast Indonesian waters. The challenges and problems faced by Indonesia domestically are more structural administrative. While externally related to Indonesia's ability to overcome the problem of new non-traditional delimitation, delineation, demarcation and threats, and Indonesia's ability to adapt and interact with other neighboring countries. ${ }^{17}$ Indonesia has a land border with 3 neighboring countries namely Malaysia, Papua New Guinea, and East Timor. The border is spread across three islands such as Kalimantan, Papua, and Southeast Nusa Tenggara, and four provinces, namely the provinces of West Kalimantan, East Kalimantan, Papua, and East Nusa Tenggara. While the sea borders sovereignty with ten countries, namely Malaysia, Papua New Guinea, East Timor, India, Thailand, Vietnam, Singapore, Philippines, Palau, and Australia.18 Understanding of borders is far more complex, because of the very close link between the physical aspects and the people who occupy the region with the state, economic activities, and local culture.

Therefore, Brunnet Jailly in his writing stated that to analyze border problems there are several elements that need attention, namely as follows: 1) market forces and trade flows, 2) government policies of countries that have direct borders (policy activities of multiple levels of adjacent borders), 3) the influence of political factors in the particular political clout of borderland communities, 4) the distinctive culture of communities in the border region (the specific cultures of borderland communities). Through understanding of the functions of this border, Brunet Jailly is believed to be able to effectively reduce problems in the border region. In the beginning the understanding of security was more associated with efforts to use and control military (conventional) capabilities in the face of threats. But there is still another security understanding, namely issues of non-conventional security understanding, such as economic, environmental, social, health, illegal workers, and human trafficking which if not handled properly can trigger disputes between countries that can disrupt national security country, and even regional global. ${ }^{19}$ Other than that, socio-economic conditions at the border result in local people depending on neighboring countries. so that

17 Author. "Pengelolaan Batas Wilayah Negara dan Kawasan Perbatasan 2011-2014". Draft Rencana Induk http://documents.worldbank.org/curated/en/871851468042279485/pdf/682610WP0P1184 Order0Areas0201102014.pdf

18 Vivi Pusvitasary. “Aktivitas Ekonomi Ilegal Di Perbatasan Indonesia-Timor Leste” Jurnal Westphalia 16.1 (2017):116.

19 Genewati Wuryandari, Keamanan Di Perbatasan Indonesia Timor Leste Sumber Ancaman dan Kebijakan Pengelolaannya (Yogyakarta: Pustaka Pelajar,2009) 
dependence on neighboring countries resulted in a decrease in the sense of nationalism. ${ }^{20}$

\section{b. Globalization}

Globalization erases and blurs the boundaries and barriers of a country. According to Anthony Giddens, globalization "abandons" the nation states in the sense that the forces that were once owned by the state, including those which underlie Keynesian economic management, have been weakened. ${ }^{21}$ The field of life that is relevantly experiencing changes and new challenges in globalization is human traffic, both legal and illegal. This pattern of human displacement, in the Indonesian context, occurs more specifically given the character of Indonesia, which is a provider of labor for neighboring countries whose economies are richer.

This character drives the emergence of out-of-country migration in the form of Indonesian migrant workers to various countries that are able to provide employment. The exploitation of Indonesian migrant workers in the form of slavery, forced labor, extortion, oppression and salaries is not paid as a manifestation of the crime of human trafficking. ${ }^{22}$

\section{c. Economic}

The problem of poverty seems to be the main reason for the question of why trafficking continues to increase. Aware of being unaware this mode has become one of the lucrative sources of income. Human trafficking is a cruel crime against human rights, which ignores a person's right to live freely, not be tortured, personal freedom, mind and conscience, various rights not to be enslaved and others. ${ }^{23}$ In puritan societies in developing countries for example, the legality of trafficking practices is carried out precisely in the name of social systems that are camouflaged into the relative norms of community culture. This condition is especially widespread in groups that have very strong economic dependence on economic forces outside their communities.

Trafficking victims generally come from poor / economically weak families, have low / low emotional education, from suburbs and rural areas,

20 M. Ishaq. "Pembinaan Nasionalisme Pemuda Perbatasan Melalui Program Pendidikan Luar Sekolah" Jurnal Ilmu Pendidikan 17.6 (2011): 459.

21 Anthony Giddens, Ketut Arya Mahardika(translator), The Third Way: The Renewal of Social Democracy (Jakarta: PT Gramedia Pustaka Utama,1999), 36.

22 Endro Sulaksono. "Disharmoni Hak Migran di Wilayah Perbatasan Berimplikasi Kejahatan Perdagangan Manusia di Luar Negeri.” Jurnal Keamanan Nasional 11.1 (2016):112.

23 Alfitra, Modus Operandi Pidana Khusus di Luar KUHP, (Jakarta: Raih Asa Sukses,2014) 127. 
although there is a possibility that there are from middle to upper economic families in urban areas. Poverty and education are low, such conditions tend to be used by certain parties for business purposes by preying on women and children, because they are easily lured / intimidated, scared, lied to, cheated, and workers with low wages. In addition, the limited employment available causes women and children to tend to become TKI / TKW abroad, with the aim of earning income to cover the family's economic burden. ${ }^{24}$

On the other side there is a public perception that working abroad will get a relatively larger salary even as a domestic helper, rather than working domestically. This condition is always used by syndicate trafficking to exploit women and children in a controlled position, even though the promised work agreement is not appropriate, even those who are exploited become prostitutes both abroad and domestically. ${ }^{25}$ In terms of maritime affairs, Indonesia as the largest archipelagic country in the world has not been able to empower maritime economic potential. This country has also not been able to transform marine resources into a source of progress and prosperity for the people of Indonesia. Indonesia is like a giant country that still sleeps. Indonesia also has a strategic position, across continents that connects advanced economies, the strategic geopolitical position provides opportunities for Indonesia as an economic pathway, for example, several strategic straits of the world economy in the NKRI region, namely the Malacca Strait, Sunda Strait, Lombok Strait, Makassar Strait and Ombai Wetar Strait. This geopolitical potential can be used by Indonesia as an Indonesian power in the political and economic arena between nations.

\section{Legal Efforts and Security Strategies in Indonesia on Handling Human Trafficking Cases}

The public's understanding of the crime of trafficking in persons relates to the attitude of legal awareness regarding the importance of rules in the form of positive law, related to the level of legal awareness (rechtsbewustzijn), therefore understanding the law is not only in terms of law in book, but more in the implementation (law in action), so that the understanding of the crime of human trafficking does not only have a conceptual order, but takes precedence at the level of implementation / application relating to legal awareness. If the regulation has been felt as a necessity, it will become a feeling of law (rechtsgevoel), so that legal regulations will apply as needed and

24 Chairul Bariah, Aturan-Aturan Hukum Trafficking (Perempuan dan Anak) (Medan: USU Press,2005) 2.

25 Ibid. 
not because of compulsion, thus the law and law enforcement will run in accordance with the rule of law. ${ }^{26}$

Given the function of law as a means of development and community renewal (law as a tool of social engineering), the law also acts as a tool to change society towards a better direction. ${ }^{27}$ Human trafficking, which is predominantly women and children, is a type of slavery, in this modern era is the impact of the multidimensional crisis experienced by Indonesia, in the news it has been declared a serious global problem and has even become a global business that has given great benefits to the perpetrators. Every year an estimated two million people are trafficked and most are women and children. ${ }^{28}$ The provisions concerning the prohibition on trafficking in persons, especially women and children, have basically been regulated in Article 297 of the Criminal Code which reads: "trafficking in women and the trade of boys who are not old enough, are threatened with imprisonment for a maximum of six years" 29 , strict human trafficking and sanctions that are too light and not commensurate with the impact suffered by victims due to human trafficking crimes.

Furthermore, on 17 April 2007 the Indonesian government finally ratified and promulgated the Law of the Republic of Indonesia Number 21 of 2007 concerning the Eradication of Crimes against Trafficking in Persons specifically regulating criminal acts of trafficking in persons. This law is expected to be able to provide a formal and material legal basis as well as to anticipate and ensnare all types of actions in processes, methods or all forms of exploitation that may occur in the practice of trafficking, both between domestic and interstate countries, both individuals and corporations. ${ }^{30}$

Since its inception, Indonesia has criminalized human trafficking by regulating article 297 of the Criminal Code, but because human trafficking has developed into organized transnational crime, it is necessary to renew the commitment to fight as stated in Presidential Decree No. 88 of 2002 concerning the National Action Plan for the Elimination of Trafficking in Women and Children and a task force that has cross-sectoral members for its implementation. This national commitment aims not only to combat human trafficking crimes, but also the root cause of the problem is poverty, lack of education and skills, lack of access, opportunities and information, and sociocultural values. ${ }^{31}$

26 Henny Nuraeny, Tindak Pidana Perdagangan Orang Kebijakan Hukum Pidana dan Pencegahannya (Jakarta: Sinar Grafika,2011), 19

27 Ibid., p. 20.

28 Rachmad Syafaat, Dagang Manusia (Jakarta: Lappera Pustaka Utama,2003) 1

29 Ibid., p. 130.

30 Alfitra, Modus Operandi Pidana Khusus di Luar KUHP (Jakarta: Raih Asa Sukses,2014) 140

31 Farhana, Aspek Hukum Perdagangan Orang di Indonesia (Jakarta: Sinar Grafika,2010) 7-8 
The government has an obligation to pay attention to security issues society. Especially the problems related to service to the wider community (public services) and the construction of various infrastructures or facilities needed by the community. ${ }^{32}$ Government governance in the sea of government in the sea concerns safety, security and law enforcement which can be said to be inadequately available even though there are many crimes and illegal transactions that have occurred lately in Indonesian waters. For this reason, it needs to be addressed as early as possible so that our sea area is safe from all danger conditions.

Considering the number of Indonesian Navy is not comparable with the extent of Indonesian waters, the hope of becoming a strong navy is still hard to achieve. At present Indonesia has a Marine Security Agency and Coordination (Badan Koordinasi Keamanan Laut, BAKORKAMLA), initially BAKORKAMLA was a joint coordination body between the Minister of Defense Security/Commander of the Armed Forces, Minister of Transportation, Minister of Finance, Minister of Justice and Attorney General's Office (KEP/D/45/XII/1972, SK. 901/M/1972, Kep.779 MK/ III/12/1972, JS.8/72/1972 and KE/JA/12/1972 dated 12 December 1972 concerning the Marine Security Coordination Agency). This joint decree was renewed with the presidential regulation of Republic of Indonesia Number 81 of 2005 which turned out to need to be refined because it was not in line with the idea of the need to reorganize the Sea Security Coordination Agency as a substitute for the Agency which was formed before 1972, in 2003 Politics and Security No. Kep. 05/Menko/ Polkam/2/2003 then formed the Security Development Planning and Law Enforcement Working Group at Sea.

Through a series of seminars and cross-sectoral coordination meetings, then on December 29, 2005 a Presidential Regulation Number 81 of 2005 was enacted concerning the Sea Security Coordination Agency (BAKORKAMLA) which became the legal basis of the BAKORKAMLA organization. To guarantee the implementation of safety and security in the sea as referred to in article 276 paragraph (1) and article 279 paragraph (3) Law number 17 of 2008 concerning Shipping, a safeguard function and enforcement of laws and regulations in the sea and coast are carried out by the Sea and Coast Guard. Sea and coast guards as referred to in article 277 paragraph (1) carry out duties:

1) Conduct surveillance and safety and security of shipping which includes the safety and security of water transportation, ports, and the protection of the maritime environment

2) Supervise the prevention and control of pollution in the sea

32 Faisyal Rani. "Strategi Pemerintah Indonesia Dalam Meningkatkan Keamanan Wilayah Perbatasan Menurut Perspektif Sosial Pembangunan” Jurnal Transnasional 4.1 (2012):1 
3) Supervision and control of salvage activities, underwater work and exploitation and exploration of marine wealth

4) Supervision and control of activities and ship traffic

5) Safeguarding navigation aids and supporting the implementation of search activities and help of the human soul at sea.

The Maritime Security Agency in order to realize its formation immediately, there are several factors that must be implemented including commitment and strong leadership from policy makers to eliminate inefficiencies in all sectors and dare to instill the vision of a maritime country. ${ }^{33}$

Besides that for border areas, management of security can be achieved through "hard border security regime" which emphasizes the direction of security forces who try to prevent infiltration from outside and inhibit citizens from crossing their borders, while "soft border security regime" places more emphasis on economic functions and socio-culture by opening the door to the widest possible extent for the outflow of people without fear of foreign infiltration. ${ }^{34}$

\section{Conclusion}

The apprehensive maritime security conditions demand systematic efforts to save Indonesian waters from security, legal and sovereignty. The fact is that Indonesia borders land and sea with 10 neighboring countries and until now Indonesia still faces national border problems, especially related to the border line with neighboring countries, so the potential threat of human trafficking is increasingly wide open. Especially with the existence of globalization which increasingly increases the risk of human trafficking because globalization diminishes the boundaries between countries. The victims of human trafficking experience many terrible things. Physical and psychological injuries often leave a permanent influence that can alienate victims from their families and from the lives of independent communities. Victims of trafficking often lose important opportunities to go through social, moral and spiritual developments. In many cases exploitation of victims of trafficking continues to increase. For this reason, the Indonesian government continues to seek various ways to reduce the problem of human trafficking, starting from legal efforts and efforts through the establishment of special institutions

33 Levina Yustitianingtyas. "Pengamanan dan Penegakan Hukum di Perairan Indonesia Sebagai Konsekuensi Penetapan Alur Laut Kepulauan Indonesia (ALKI)" Pandecta Journal 10.2 (2015)

34 Genewati Wuryandari, Keamanan Di Perbatasan Indonesia Timor Leste Sumber Ancaman dan Kebijakan Pengelolaannya (Yogyakarta: Pustaka Pelajar,2009) 
such as BAKORKAMLA. Whereas efforts implemented to reduce human trafficking in border areas are the application of hard border security regimes and soft border security regimes where freedom to open the border door for in and out flows is still maintained and monitored so that illegal smuggling / trafficking processes such as human trafficking do not occur. But as citizens, they also have to participate in state security efforts, such as by trying to decide the stigma of people who think that working abroad will make more money.

\section{E. Acknowledgment}

The Authors would like to thank profusely to the editor of the Indonesian Journal of Advocacy and Legal Services, Faculty of Law Universitas Negeri Semarang. In addition, The Authors also thank to Center for Research and Case Analysis of Indonesian Constitutional Court and Faculty of Law Universitas Muhammadiyah Malang.

\section{F. Declaration of Conflict of Interest}

The authors state that there is no potential conflict of interest in the research, authorship, and/or publication of this article.

\section{G. Funding}

The authors do not obtain financial support from any party for research, authorship, and/or publication of this article.

\section{H. References}

Alfitra, A. (2014). Modus Operandi Pidana Khusus di Luar KUHP. Jakarta: Raih Asa Sukses.

Andari, A. J. (2011). Analisis Viktimasi Struktural Terhadap Tiga Korban Perdagangan Perempuan dan Anak Perempuan. Jurnal Kriminologi Indonesia, $7(3)$, 307-309. http://www.ijil.ui.ac.id/index.php/jki/article/view/1082/994

Andrasukma, A. N. (2014). "Kerjasama Pemerintah dan INGO terhadap Child Trafficking di Thailand Tahun 2008-2013", Thesis, Surabaya: Universitas Airlangga.

Anonim. (2010). "Isu Keamanan Maritim Regional". Tabloid Diplomasi, September 15 , 2010. http://www.tabloiddiplomasi.org/isu-keamanan-maritim-regional/ 
Bariah, C. (2005). Aturan-Aturan Hukum Trafficking (Perempuan dan Anak). Medan: USU Press.

DSF Indonesia. (2011). Draf Rencana Induk Pengelolaan Batas Wilayah Negara dan Kawasan Perbatasan 2011-2014. Jakarta: Decentralization Support Facility. Retrieved from http://documents.worldbank.org/curated/en/871851468042279485/pd f/682610WP0P11840rder0Areas0201102014.pdf

Farhana, F. (2010). Aspek Hukum Perdagangan Orang di Indonesia. Jakarta: Sinar Grafika.

Friebel, G., \& Guriev, S. (2006). Smuggling humans: a theory of debt-financed migration. Journal of the European Economic Association, 4(6), 10851111.

Giddens, A. (1999). The Third Way: The Renewal of Social Democracy. Jakarta: PT Gramedia Pustaka Utama.

Indirati, N. (2014). Pengembangan Model Perlindungan Hukum Terhadap Anak Sebagai Korban Perdagangan di Indonesia. Jurnal Dinamika Hukum, 14(3), 406-418.

Ishaq, M. (2012). Pembinaan Nasionalisme Pemuda Perbatasan Melalui Program Pendidikan Luar Sekolah. Jurnal Ilmu Pendidikan, 17(6), 459-468.

Jayanti, L., Sentinuwo, S. R., Lantang, O. A., \& Jacobus, A. (2016). Analisa Pola Penyalahgunaan Facebook Sebagai Alat Kejahatan Trafficking Menggunakan Data Mining. Jurnal Teknik Informatika, 8(1), 30-35. https://ejournal.unsrat.ac.id/index.php/informatika/article/viewFile/1 $2231 / 11811$

Nainggolan, N. (2015). Agenda Poros Maritim Dunia dan Perubahan Lingkungan Strategis. Jakarta: P3DI. Nasution, A. M., Wiranto, S., \& Madjid, A. (2018). Sinergi Antara Kelompok Masyarakat Pengawas (Pokmaswas) dan Pembinaan Desa Pesisir (Bindesir) untuk Membentuk Satuan Armada Nelayan (Satarmanel) dalam Rangka Mencegah Ancaman Keamanan Maritim. Jurnal Keamanan Maritim, 4(1), 25-46.

Nuraeny, H. (2011). Tindak Pidana Perdagangan Orang Kebijakan Hukum Pidana dan Pencegahannya. Jakarta: Sinar Grafika.

Puspahapsari, A., Utomo, T. C., \& Wahyudi, F. E. (2015). Implementasi Counter-trafficking International Organization for Migration (IOM) dalam Menanggulangi Perdagangan Manusia di Indonesia Tahun 2007-2013. Journal of International Relations, 1(3), 18-24.

Pusvitasary, V., \& IP, S. (2017). Aktivitas Ekonomi Ilegal di Perbatasan Indonesia-Timor Leste. Jurnal Westphalia, 16(1), 115-130.

Rani, F. (2012). Strategi Pemerintah Indonesia dalam Meningkatkan Keamanan Wilayah Perbatasan Menurut Perspektif Sosial Pembangunan. Jurnal Transnasional, 4(1), 1914-1928. https://transnasional.ejournal.unri.ac.id/index.php/JTS/article/view/ $3189 / 3105$ 
Ritzer, G. (2010). The Globalization of Nothing. Yogyakarta: Atmajaya University.

Shemella, P. (2016). Introduction of Maritime Violence, Global Response to Maritime Violence. Palo Alto: Stanford University Press.

Subagyo, A., \& Wirasuta, D. S. (2013). Penyelundupan Manusia dan Ancaman Keamanan Maritim Indonesia. Jurnal Pertahanan, 3(3), 151-170.

Sulaksono, E. (2016). Disharmoni Hak Migran di Wilayah Perbatasan Berimplikasi Kejahatan Perdagangan Manusia di Luar Negeri. Jurnal Keamanan Nasional, 2(1), 111-140.

Syafaat, R. (2003). Dagang Manusia. Jakarta: Lappera Pustaka Utama.

Wulansari, E. M. (2014). Penegakan Hukum di Laut Dengan Sistem Single Agency Multy Tasks. Rechtsvinding: Media Pembinaan Hukum Nasional, 3(1), 1-6.

Wuryandari, G. (2009). Keamanan di Perbatasan Indonesia Timor Leste Sumber Ancaman dan Kebijakan Pengelolaannya. Yogyakarta: Pustaka Pelajar.

Yustitianingtyas, L. (2015). Pengamanan dan Penengakan Hukum di Perairan Indonesia sebagai Konsekuensi Penetapan Alur Laut Kepulauan Indonesia (ALKI). Pandecta: Jurnal Penelitian Ilmu Hukum (Research Law Journal), 10(2), 143-152. 